\title{
Evaluation of Small Trade Extension Programs
}

\author{
Diah Pranitasari*, Lilik Trianah \\ Department of Management \\ Sekolah Tinggi Ilmu Ekonomi Indonesia \\ Jakarta, Indonesia \\ *diah_pranitasari@stei.ac.id
}

\begin{abstract}
This study evaluates the counseling program of small traders in Pisangan Timur, Pulo Gadung, East Jakarta, using the Kirkpatrick method, namely from the four level aspects, namely the reaction level, learning level, behavior level, and behavior level, and result level. This research uses quantitative analytic descriptive method. Data collection was carried out by distributing questionnaires to small traders in Pisangan Timur, Pulo Gadung, East Jakarta. The results showed that in general the description of the evaluation of the extension program at the four levels of the Kirkpatrick model which included reaction rates, learning levels, behavior levels and outcome levels all gave excellent results for the extension program participants.
\end{abstract}

Keywords: reaction, learning, behavior, results

\section{INTRODUCTION}

The current condition of the Indonesian economy makes people feel increasingly expensive the costs of fulfilling the necessities of life and increasingly difficult to find work to meet their needs, making people have to think creatively and be able to read opportunities to create opportunities in meeting the needs of life.

Unemployment in Indonesia is increasing every day by day, opportunities and vacancies are minimal, and low education is the trigger for everyone to set up a small and medium-sized business. Entrepreneurship is now a trend among Indonesian people. With only capital skills and abilities in managing it they can get a promising profit. But in practice it is not easy to start a business. The fear of failure and loss must always haunt the entrepreneurs when starting a business. The intention and courage in taking risks is the main capital in opening a new business. But courage without being accompanied by entrepreneurial skills often plunges into situations of prolonged failure.

Housewives as husband partners in managing household finances, feel the same way in meeting the needs of life. Being a discourse for housewives so that not only rely on the livelihood of their husbands, but housewives are demanded to be more productive in order to help their husbands in meeting their needs.

Based on the above problems, community service is carried out, namely the academic community activities that utilize Science and Technology to advance the welfare of the community and educate the nation's life. Through an extension program with the theme Developing Knowledge and Growing
Entrepreneurial Interests for housewives who are members of the Sabila study in Pisangan Timur, Pulo Gadung, East Jakarta in December 2015, the aim of the extension program is the development of knowledge and insight for member of the Sabila study so that it becomes a more productive human being and can increase self-confidence and help the family's economy.

The initial counseling was very well responded by the participants, this can be seen from the enthusiasm of the participants as evidenced by their courage to engage in small businesses that they started, including some who sell fried foods, steamed rice, grocery, and many more. So it needs to be a concern for us to be able to provide effective counseling so that we can accompany participants to become successful small traders.

Seeing the enthusiasm and requests of the participants after the initial counseling was held, then continued counseling was carried out to support the motivation of the participants who had dared to try to run a new small business. Subsequen counseling was carried out with total implementation to date 4 (four) extension activities. The extension materials are as follows:

TABLE I. THE EXTENSION MATERIALS

\begin{tabular}{|l|l|l|}
\hline No & \multicolumn{1}{|c|}{ Counseling } & Implementation \\
\hline 1 & $\begin{array}{l}\text { Develop knowledge and foster } \\
\text { entrepreneurial interest }\end{array}$ & December 2015 \\
\hline 2 & $\begin{array}{l}\text { Food production and packaging that is safe } \\
\text { for human health }\end{array}$ & January 2016 \\
\hline 3 & $\begin{array}{l}\text { Determination of production costs and } \\
\text { product selling prices }\end{array}$ & January 2017 \\
\hline 4 & Marketing strategy & June 2018 \\
\hline
\end{tabular}

In conducting counseling, counseling is certainly not perfect, there are still weaknesses that we have to fix. The intended weaknesses can be from participants, instructors, learning methods, learning processes, or learning infrastructure. Therefore, it is necessary to evaluate the counseling programs that have been carried out so far. This can be used as a reference in planning future counseling, so that counseling programs can be arranged that can be more targeted.

\section{RESEARCH METHOD}

The location of the study was conducted at small traders in the Pisangan Timur, Pulo Gadung, East Jakarta, which was 
The data collection in this study was carried out by incorporated in the Sabila Ta'lim Assembly. The population in this study were all small traders in Pisangan Timur, Pulo Gadung, East Jakarta. With a total population of 50 small traders. The sample used for this study was 50 small traders with saturated sampling technique that is using the entire population.

This study used a four-level evaluation model first recognized in 1959 when Donald L. Kirkpatrick wrote four series of articles entitled "Techniques for Evaluating Training Programs" published in Training and Development, the journal of The American Society for Training and Development (ASTD) [1]. The four-level evaluation method represents a sequence of each stage for evaluating training programs [2]. The purpose of the sequence is that each level must be done in stages. This is because each level in the four-level model is important and each level impacts the next level [3]. The four levels are:

- Level 1- Reaction,

- Level 2- Learning (Learning),

- Level 3- Behavior, and

- Level 4- Results.

TABLE II. THE OPERATIONAL DEFINITION OF THIS RESEARCH IS EXPLAINED AS FOLLOWS

\begin{tabular}{|c|c|c|c|}
\hline Level & Definition & Indicator & $\begin{array}{c}\text { How to } \\
\text { Measure }\end{array}$ \\
\hline Reaction & $\begin{array}{l}\text { Participants' } \\
\text { satisfaction with the } \\
\text { extension program } \\
\text { that has been } \\
\text { followed, especially } \\
\text { regarding the material, } \\
\text { facilitators, training } \\
\text { methods acilities } \\
\text { supporting faciond } \\
\text { where the satisfaction } \\
\text { will bring a reaction } \\
\text { from the participants }\end{array}$ & $\begin{array}{l}\begin{array}{l}\text { Extension } \\
\text { material }\end{array} \\
\text { Extension } \\
\text { facilitators } \\
\text { Counseling } \\
\text { methods } \\
\text { Supporting } \\
\text { facilities }\end{array}$ & $\begin{array}{l}\text { Fill out the } \\
\text { Questionnaire } \\
\text { Study } \\
\text { secondary data }\end{array}$ \\
\hline Learning & $\begin{array}{l}\text { Learning about } \\
\text { entrepreneurship, } \\
\text { marketing, } \\
\text { production, prices } \\
\text { understood by the } \\
\text { participants }\end{array}$ & $\begin{array}{l}\text { Understanding of } \\
\text { the extension } \\
\text { participants } \\
\text { about the } \\
\text { information } \\
\text { materials that } \\
\text { have been } \\
\text { obtained }\end{array}$ & $\begin{array}{l}\text { Questionnaire } \\
\text { filling }\end{array}$ \\
\hline Behavior & $\begin{array}{l}\text { Implementation of } \\
\text { post-counseling } \\
\text { behavior for small } \\
\text { traders in the } \\
\text { workplace } \\
\text { includes which } \\
\text { attitudes, attention and } \\
\text { actions }\end{array}$ & $\begin{array}{l}\text { Capabilities } \\
\text { Attitude } \\
\text { Attention } \\
\text { Actions }\end{array}$ & $\begin{array}{l}\text { Fill out the } \\
\text { questionnaire } \\
\text { Observation } \\
\text { Semi- } \\
\text { structured } \\
\text { interviews }\end{array}$ \\
\hline Results & $\begin{array}{l}\text { The success of the } \\
\text { extension program } \\
\text { from the perspective } \\
\text { of small traders due to } \\
\text { an increase in the } \\
\text { performance } \\
\text { competence } \\
\text { participants }\end{array}$ & $\begin{array}{l}\text { Improvement / } \\
\text { development of } \\
\text { participant } \\
\text { entrepreneurship }\end{array}$ & $\begin{array}{l}\text { Questionnaire } \\
\text { Completion } \\
\text { Semi- } \\
\text { structured } \\
\text { interviews }\end{array}$ \\
\hline
\end{tabular}

distributing questionnaires to small traders in Pisangan Timur, Pulo Gadung, East Jakarta. Questionnaires were distributed to small traders in order to know the description of research evaluations at the level of reaction, learning and outcome levels and to find out the effectiveness of the extension program. However, to sharpen the results and add information, semistructured interviews were conducted with respondents and direct observation of the respondent's small business management.

\section{RESULTS AND DISCUSSION}

\section{A. Results}

Respondents in this study were mothers of the Majelis Ta'lim Sabila study group in Pisangan Timur, Pulo Gadung, East Jakarta, who are now entrepreneurs as small traders, totaling 50 people.

In this study, there were 3 (three) individual characteristics that were asked to respondents, namely age, last education and employment status. This was done to find out how the frequency distribution of the characteristics of individuals who were respondents in this study. The characteristics of respondents are $46 \%$ of respondents aged $41-50$ years, $74 \%$ of respondents have a high school education, and $90 \%$ of respondents work as housewives.

The results of the statistical description of the reaction level, the level of learning, the level of behavior, and the level of results are explained as follows:

1) Response rate distribution: The level of reaction is the respondent's satisfaction with the counseling program that has been followed, especially regarding the material, facilitators, training methods and supporting facilities where the satisfaction will generate reactions from the participants. In the evaluation of the reaction level there are 10 items submitted by researchers to respondents. The frequency distribution of respondents' responses regarding their satisfaction with the extension program obtained a description of the results of the study in which the average respondent's response to the reaction statement averaged 3.38 or very good. And a maximum index of 3.78 is a statement of counseling material that is presented clearly and systematically. While the lowest index is 2.38 which is a statement of the presence of tools/learning media, such as projectors, laptops, and teaching aids.

2) Distribution of learning level answers: The level of learning is the result of respondents 'learning about entrepreneurship, marketing, production, prices understood by respondents Respondent's perceptions of learning levels, statistically descriptive At the learning level, the indicator is the extent to which respondents or extension participants understand the counseling material delivered by the instructors namely regarding entrepreneurship, marketing, production, and pricing. At the level of learning this is done by giving written tests to the participants. The average questions answered correctly by the participants were $97 \%$. And the 
questions understood by the participants were entrepreneurship, packaging and marketing material. While the minimum question understood by the participants is pricing.

For criticism and suggestions given by respondents, the counseling program conducted so far has been good, respondents are satisfied with the implementation of the extension program so far and there are requests from respondents so that counseling can be done at least once a year. Input from respondents on the topic of counseling that should be carried out in the next period is:

- Marketing

- Buying and selling online

- Financial management

- Business development

- The rental service business

- Educate children

3) Distribution of behavior level answers: The level of behavior is the implementation of post-counseling behavior for small traders in the workplace which includes abilities, attitudes, attention and actions. Respondents' perceptions about the level of behavior, statistically descriptive can be seen from the average response of respondents to the statement of behavior that is an average of 3.42 or very good. And a maximum index of 3.76 is a statement to always try to be honest in trading, while a minimum index of 2.68 is a statement of ability to promote merchandise.

4) Distribution of results-level answers: Outcome level is the success of the extension program from the point of view of small traders due to an increase in the performance/ competency of the respondents 'perceptions about the level of results, in descriptive statistics the respondents' average answers to the statement of average results are 3.4 or very good. And the 2.72 main index is a statement of the amount of merchandise sold by respondents has increased. As for the minimum index, always try to be honest in trading, while the maximum index is 3.82 , which is the statement of respondents who guarantee that their merchandise is always safe for health.

\section{B. Discussion}

This study records the results of numerical measurements of respondents 'perceptions of the four research variables, as presented in the previous section, below is a recapitulation of the distribution of respondents' perceptions of the level of reaction, level of learning, level of behavior, and level of results.

TABLE III. RECAPITULATION OF RESPONDENT'S PERCEPTIONS

\begin{tabular}{|l|l|l|l|l|}
\hline \multicolumn{1}{|c|}{ Level } & \multicolumn{1}{|c|}{ Index } & Average Index & \multicolumn{1}{c|}{ Minimum Index } & \multicolumn{1}{c|}{ Maximum Index } \\
\hline Reaction & Satisfaction & Very good & $\begin{array}{l}\text { aids / learning media, such as extension materials are presented clearly and } \\
\text { projectors, laptops, and teaching aids } \\
\text { systematically }\end{array}$ \\
\hline Learning & Understanding of Material & Very Good & $\begin{array}{l}\text { Material that is less understood by } \\
\text { respondents is price fixing material }\end{array}$ & $\begin{array}{l}\text { Material that is understood by respondents is } \\
\text { entrepreneurial, packaging and marketing material }\end{array}$ \\
\hline Behavior & Implementation Behavior & Very good & ability to promote merchandise & always try to be honest in trading \\
\hline Result & $\begin{array}{l}\text { Success of Counseling } \\
\text { Program }\end{array}$ & Very good & $\begin{array}{l}\text { number of merchandise sold by } \\
\text { respondents has increased }\end{array}$ & $\begin{array}{l}\text { Respondents guarantee that their merchandise is } \\
\text { always safe for health }\end{array}$ \\
\hline
\end{tabular}

1) Evaluation of reaction rate: Based on the results of research conducted by distributing questionnaires to 50 respondents who were counseling participants, it is known that the response rate or satisfaction of respondents to the counseling program according to the respondents' assessment gave positive results with very good categories. From this it can be said that almost all extension participants were satisfied with the implementation of the extension program from the material, facilitators, methods and supporting facilities. Besides that, the results of the semi-structured interview found that the average respondent was satisfied with the implementation of the counseling program.

When viewed more deeply, from the results of the distribution of respondents' answers to the questionnaire statements submitted by researchers all statements have a high index or are included in the excellent category, especially in terms of presenting counseling material that is assessed presented clearly and systematically. But there is one statement that has an index of 2.38 or included in the good category, namely the provision of tools/learning media, such as projectors, laptops, and props. This can be used as input for the implementation of subsequent counseling to improve teaching aids/learning media that are recognized by the implementation of extension programs are still very limited.

Based on the level of respondent's reaction or satisfaction of the participants of the extension program, the researcher concluded that the counseling carried out so far has given satisfaction to the participants of the counseling.

2) Learning level evaluation: Learning can be defined as the extend to which participants have attitudes, improving knowledge and or increasing skills as a result of attending the program [4]. Learning can be defined as a change of attitude, improvement of knowledge and/or improvement in the skills of participants after completing the extension program. The trainee is said to have learned if he has experienced a change in attitude, increased knowledge, and improved skills. Evaluation of the level of learning means measuring the extent of the impact of the extension program that participants participated in in terms of increasing knowledge, skills and behavior about something that has been learned in the extension program. In 
this case, this research is focused on how far the participants' knowledge is in understanding pre-tithing material.

The counseling program material that has been implemented includes developing knowledge and fostering an interest in entrepreneurship, food production and packaging that is safe for human health, setting production costs and product selling prices, and marketing strategies. To find out the participant or respondent's understanding, a written test with questions related to the material is carried out, besides that a question and answer session is also conducted directly on the participants of the counseling.

There are 10 (ten) questions given in writing to participants. Based on the results of the research described in the previous chapter, it can be seen that the level of learning or understanding of the participants of the extension to the extension material gives positive results with an average level of correct answers of $97 \%$. From these results it can be said that the average extension participant can answer the questions given by the researcher correctly. Or in other words the extension participants are able to understand the extension material that has been given well.

In addition to the participants who on average were able to understand the material provided in the counseling, there were some participants who still did not understand the pricing material, because some participants gave incorrect answers to the question of pricing. This can be a reference for the organizers of the extension program to be able to better present the material more clearly about product pricing.

From the results above, the researcher can conclude that the level of learning of the extension participants, in this case the increase in knowledge, skills, and behavior of the counselors can be said to be very good.

3) Behavioral level evaluation: Behavioral level evaluation is used to find out whether new skills, knowledge or attitudes as a result of counseling programs are actually utilized and applied in daily work behavior. The aim to be achieved in evaluating the level of behavior is to ensure that counseling has a positive influence on the work of the participants.

In this study, researchers used 4 (four) indicators, namely the ability, attitude, attention and action. From the results of the study described in the previous section, it was found that the average index of behavior level was 3.42 or included in the excellent category. This means that the extension program has a positive impact on the behavior of participants or participants actually apply what they have gained in counseling in their daily work behavior.

The extension participants gave very good ratings for their abilities, attitudes, attention and actions, especially in terms of honesty in trading that obtained a maximum index of 3.76. But there is still an assessment of statements that have an index with a good category, namely the ability to promote merchandise and the ability to set a more competitive selling price. This can be input for organizing the extension program to be able to better present material that is clearer and easier to understand by participants, especially in improving the ability to promote goods and determine a more competitive selling price.
4) Outcome evaluation: Outcome evaluation focuses on the end result that occurs because participants have followed a counseling program. Included in the final output category of an extension program include an increase in production, an increase in quality, a decrease in costs, and an increase in profits.

From the results of the research described in the previous section, it can be seen that the participants have experienced an increase in production, an increase in profits or an increase in quality. This can be seen from the results of the average index of 3.4 or into the excellent category.

Indicators that can evaluate results are an increase in performance/competence of participants. So it can be concluded that the participants experienced an increase in performance or competence after attending the counseling program. The statements on the evaluation of results given to respondents were 10 statements, and all statements had an index above 3.2 or very good especially in the statement that participants guaranteed that their merchandise was always safe for health.

In addition, there were still 2 (two) statements which had an index of less than 3.2 or included in the good category, namely the number of merchandise sold by the participants increased and the number of buyers of the merchandise of the participants increased. This can be used as input for program organizers to be able to further deepen marketing materials, especially in promotion.

5) Interview and observation: In this research, besides carried out by collecting data using a questionnaire, direct observations and interviews were also conducted to obtain a clearer picture, especially in the evaluation of behavior and results.

By using semi-structured interviews based on material that has been delivered in counseling that is developing knowledge and fostering entrepreneurial interests, food production and packaging that is safe for human health, determining production costs and product selling prices, and marketing strategies, the researchers make direct observations of participant. From direct observation and interviews it was found that there was an increase in the participants' desire to do entrepreneurship. This can be seen by the increasing number of participants who want to try to run a small business, such as selling yellow rice, gethuk, tofu and clothing.

From the observations and interviews it was found that there was an increase in food production and packaging of the participants in trading, namely by using materials and packaging methods that were safe for health, as seen in gethuk traders who previously used newspaper paper to wrap the gethuk now using banana leaves. It also looks like the yellow rice traders who pack their wares with special mica plastic to withstand heat.

In determining the cost of production, researchers also found an increase in the participants, as did the yellow rice trader who prefers to open merchandise at home and receive orders in large parties that he previously rented a place on the roadside. It is also done by way of mouth marketing through recitation or social gathering. From the results of direct 
- Learning level: In addition to the participants who on average were able to understand the material provided in counseling, there were some participants who still did not understand the pricing material, because some participants gave incorrect answers to the question of pricing. This can be a reference for the organizers of the extension program to be able to better present the material more clearly about product pricing.

- Behavior level: There is an assessment statement that has an index with a good category, namely the ability to promote merchandise and the ability to set a more competitive selling price. This can be input for organizing the extension program to be able to better present material that is clearer and easier to understand by participants, especially in improving the ability to promote goods and determine a more competitive selling price.

Overall description of the evaluation of the extension program at the four levels of the Kirkpatrick model [4,5] which includes:

- Reaction rate: Respondents 'satisfaction with the extension program according to the respondents' assessment gave positive results in the very good category. From this it can be said that almost all extension participants were satisfied with the implementation of the extension program from the material, facilitators, methods and supporting facilities.

- Learning level: The level of learning or understanding of the extension participants to the extension materials gave positive results with an average level of correct answers of $97 \%$. From these results it can be said that the average extension participant can answer the questions given by the researcher correctly. Or in other words the extension participants are able to understand the extension material that has been given well.

- Level of behavior: The level of behavior that is the ability, attitude, attention and action. From the results of the study had a positive impact on the behavior of the participants or the participants actually applied what they had gained in counseling in their daily work behavior.

- Yield rate: By seeing an increase in the performance / competence of the participants, it shows that the participants experienced an increase in performance or competence after attending the counseling program.

In evaluating the level of reaction, there is still knowledge or ability that is still poorly understood by the participants namely:

- Reaction rate: There is one statement that has an index of 2.38 or is categorized as good, namely the provision of aids/learning media, such as projectors, laptops and props. This can be used as input for the implementation of subsequent counseling to improve teaching aids/learning media that are recognized by the implementation of extension programs are still very limited.
- Rate of results: There are 2 (two) statements that have an index of less than 3.2 or fall into the good category, namely the number of merchandise sold by the participant is increasing and the number of buyers of the participating merchandise is increasing. This can be used as input for program organizers to be able to further deepen marketing materials, especially in promotion.

\section{SugGestion}

- Need to be studied again for organizers of extension programs to deepen marketing materials, such as promotions and selling prices. This is still felt by the participants less so it is expected to increase the ability of participants to promote their merchandise with competitive selling prices so as to increase the amount of merchandise sales and increase revenue.

- Counseling needs to be done with materials that are tailored to the needs of participants, namely online marketing and financial management.

\section{REFERENCES}

[1] M. A. M. Yusoff, J. Ahmad, A. N. Mansor, R. Johari, Kamisah Othman, N. C. Hassan, "Evaluation of School Based Assessment Teacher Training Programme", Creative Education, Vol.7, no. (4), 2016.

[2] B, Meghe, V. P. Bhise, and A, Muley, "Evaluation of Training and Development Practices of CTPS Using the Kirkpatrick Method: A Case Study", International Journal of Application or Innovation Engineering \& Management, pp.2319-4847, 2013.

[3] H. M. Abdulghani, S. A. Shaik, N. Khamis, A. A. Al-dress, M. Irshad, and M. S. Khalil, "The Kirkpatrick's Model: Translating Theory Into Practice". Journal Medical Teacher, vol. 36, 2014.

[4] Ö. G. Ulum, "Program Evaluation through Kirkpatrick's Framework". Pacific Business Review International, vol. 8, Issue 1, July 2015.

[5] S. Farjad, "The Evaluation Effectiveness of training courses in University by Kirkpatrick Model (case study: Islam shahr university)", Procedia - Social and Behavioral Sciences, vol. 46, pp.2837 - 2841, 2012. 